\title{
PENINGKATAN AKTIVITAS DAN HASIL BELAJAR IPS PADA MATERI PERJUANGAN MELAWAN PENJAJAH MELALUI MODEL PEMBELAJARAN WORD SQUARE
}

\author{
Nazaratun Wahidah \\ Madrasah Ibtidaiyah Negeri 6 Tapin \\ Email : nazaratunwhd@gmail.com \\ Website : https://jurnal.uin-antasari.ac.id/index.php/ptkpend/index \\ Received: Juni 2019; Accepted: Agustus 2019; Published: Agustus 2019
}

\begin{abstract}
The matter of this study was the lack of students' interest in the subject of social studies which is talked about the struggle against invaders. This caused low learning activity on students and their learning outcomes. The research method used a type of qualitative research with Classroom Action Research (CAR) approach by the design of 2 cycles. The subjects of this study were 24 students of the $6^{\text {th }}$ grade at MIN (Islamic Elementary) 6 Tapin. The results showed that the activity of students in the first cycle of $1^{\text {st }}$ meeting was $62.80 \%$, the $2^{\text {nd }}$ meeting was $71.87 \%$. Meanwhile, in the second cycle of $1^{\text {st }}$ meeting was $81.45 \%$ and at the $2^{\text {nd }}$ meeting was $97.90 \%$. Student learning outcomes have increased and able to achieve mastery learning standard individually in the first cycle of the $1^{\text {st }}$ meeting at $41.66 \%$ then it increased at $2^{\text {nd }}$ meeting by $75.00 \%$. Furthermore, at the second cycle of $1^{\text {st }}$ meeting amounted to $91.70 \%$ and increased at $2^{\text {nd }}$ meeting by $95.83 \%$. Thus, the Word Square learning method can improve student activities and learning outcomes.
\end{abstract}

Keywords: learning outcomes; learning activities; social studies; word square

\begin{abstract}
ABSTRAK
Permasalahan dalam penelitian ini adalah kurangnya minat siswa pada pelajaran IPS materi perjuangan melawan penjajah yang mengakibatkan rendahnya aktivitas dan hasil belajar siswa. Metode penelitian menggunakan jenis penelitian kualitatif dengan pendekatan Penelitian Tindakan Kelas (PTK) dengan rancangan 2 siklus. Subjek penelitian ini adalah siswa kelas V MIN 6 Tapin yang berjumlah 24 orang. Hasil penelitian menunjukkan bahwa aktivitas siswa siklus I pertemuan 1 adalah $62,80 \%$, pertemuan 2 adalah $71,87 \%$. Sedangkan pada siklus II pertemuan 1 adalah sebesar $81,45 \%$ dan pada pertemuan 2 sebesar $97,90 \%$. Hasil belajar siswa mengalami peningkatan dan dapat mencapai ketuntasan belajar secara individual pada siklus I pertemuan 1 sebesar $41,66 \%$ kemudian meningkat pada pertemuan 2 sebesar 75,00\%. Pada siklus II pertemuan 1 sebesar 91,70\% dan meningkat pada pertemuan 2 sebesar 95,83\%. Jadi, metode pembelajaran Word Square dapat meningkatkan aktivitas dan hasil belajar siswa.
\end{abstract}

Kata kunci: hasil belajar; aktivitas belajar; IPS; word square

\section{PENDAHULUAN}

Menurut Undang-undang Sistem Pendidikan Nasional Nomor 20 Tahun 2003 Pasal 17, pendidikan dasar didefinisikan sebagai jenjang pendidikan yang melandasi jenjang pendidikan menengah. Pendidikan dasar berbentuk sekolah dasar (SD) dan madrasah ibtidaiyah (MI) atau bentuk lain yang sederajat serta sekolah menengah pertama 
(SMP) dan madrasah tsanawiyah (MTs) atau bentuk lain yang sederajat. Oleh karena itu, madrasah sebagai salah satu bentuk pendidikan dasar diharapkan dapat meningkatkan efektivitas dan efesiensi penyelenggaraan pendidikan.

Tujuan kurikulum adalah tujuan yang ingin dicapai oleh setiap bidang studi/mata pelajaran. Jadi, suatu bidang studi dan mata pelajaran tersebut harus berjalan sesuai kurikulum agar terselenggara suatu proses pembelajaran. Salah satu bidang studi/mata pelajaran yang termuat dalam kurikulum di madrasah ibtidaiyah adalah IPS (Ilmu Pengetahuan Sosial).

IPS (Ilmu Pengetahuan Sosial) merupakan integrasi dari berbagai cabang ilmu-ilmu sosial, seperti sosiologi, sejarah, geografi, ekonomi, politik, hukum dan budaya. Ilmu pengetahuan sosial dirumuskan atas dasar realitas dan fenomena sosial yang diwujudkan pada satu pendekatan interdisipliner dari aspek ilmu-ilmu sosial (Targana, 2009).

IPS bagi pendidikan dasar merupakan hasil perpaduan dari mata pelajaran geografi, ekonomi, ilmu politik, ilmu hukum, sejarah, antropologi, psikologi, dan sosiologi. Perpaduan ini disebabkan mata pelajaran tersebut memiliki objek material kajian yang sama yaitu manusia (Nurdianti, 2016). Mata pelajaran Ilmu Pengetahuan Sosial di madrasah ibtidaiyah yang diajarkan umumnya diarahkan dalam rangka menyiapkan siswa untuk belajar lebih lanjut ke jenjang berikutnya dan mempersiapkan siswa untuk terjun ke masyarakat serta memasuki dunia kerja yang tersedia.

Sejalan dengan tujuan di atas, maka tujuan pendidikan IPS di madrasah ibtidaiyah adalah : 1) membekali anak didik dengan pengetahuan sosial yang berguna dalam kehidupannya kelak di masyarakat; 2) membekali anak didik dengan kemampuan mengidentifikasi, menganalisis dan menyusun alternatif pemecahan masalah sosial yang terjadi dalam kehidupan masyarakat; 3) membekali anak didik dengan kemampuan berkomunikasi dengan sesama warga masyarakat dan berbagai bidang keilmuan serta bidang keahlian; 4) membekali anak didik dengan kesadaran, sikap mental yang positif dan keterampilan terhadap pemanfaatan lingkungan hidup yang menjadi bagian dari kehidupan tersebut; 5) membekali anak didik dengan kemampuan mengembangkan pengetahuan dan keilmuan IPS sesuai dengan perkembangan kehidupan, masyarakat, ilmu pengetahuan dan teknologi.

Selama ini ada yang berasumsi bahwa penggunaan media belajar menggunakan alat yang diraba dan dimanipulasi oleh siswa sulit dilakukan dalam proses pembelajaran IPS di madrasah ibtidaiyah. Bahkan ada yang beranggapan bahwa pelajaran IPS banyak bersifat cerita lisan, dongeng belaka dari guru di muka kelas. Berdasarkan hal itu, maka peran guru sebagai pendidik mempunyai tujuan utama dalam kegiatan pembelajaran IPS di madrasah yaitu menciptakan suasana belajar yang menyenangkan, dapat menarik minat dan antusias siswa serta dapat memotivasi siswa untuk senantiasa belajar dengan baik dan semangat. Untuk mencapai tujuan tersebut maka guru harus terampil dalam memilih model pembelajaran yang tepat sesuai dengan materi pembelajaran.

Dalam proses pembelajaran IPS, ragam pendekatan dan metode yang diterapkan disesuaikan dengan materi yang menjadi pokok bahasan. Keragaman pendekatan dan metode yang diterapkan pada proses pembelajaran IPS dapat mempertahankan suasana yang tetap hangat dan menarik sehingga para peserta didik tidak dihinggapi dengan kejenuhan dan kebosanan.

Kenyataan yang terjadi menunjukkan bahwa hasil belajar IPS materi perjuangan melawan penjajah pada siswa kelas V Madrasah Ibtidaiyah Negeri 6 Tapin Tahun Ajaran 2018/2019 masih belum memuaskan. Hal ini dapat dilihat 
Vol. 5, No. 1, Hal (15-22)

dari laporan hasil belajar siswa pada mata pelajaran IPS Madrasah Ibtidaiyah Negeri 6 Tapin Tahun Ajaran 2018/2019 tentang materi perjuangan melawan penjajah masih rendah. Dari 24 orang siswa yang mempunyai nilai $\geq 65$ ke atas hanya 8 orang, sedangkan 16 siswa lainnya hanya memperoleh nilai $<65$. Data menunjukkan bahwa masih banyak siswa yang belum memenuhi standar perolehan hasil belajar yang diharapkan atau di bawah KKM yang ditetapkan.

Banyak faktor penyebab rendahnya hasil belajar siswa kelas V Madrasah Ibtidaiyah Negeri 6 Tapin, salah satunya yang paling menonjol adalah kurang minatnya siswa pada pelajaran IPS materi perjuangan melawan penjajah dikarenakan materi lebih kepada pengetahuan yang bersifat hafalan sehingga siswa lemah dalam penguasaan konsep. Hal ini mengakibatkan anak terlihat pasif, kurang bersemangat, kurang perhatian, kurang bergairah, cepat bosan dan tidak termotivasi dalam belajar sehingga materi yang diberikan tidak dapat diserap dengan baik.

Apabila keadaan tersebut tidak diatasi maka terjadi permasalahan dalam pembelajaran antara lain: siswa kebingungan, kesulitan dalam mencerna pembelajaran dan siswa asyik bermain ketika guru menerangkan. Oleh karena itu, dibutuhkan minat siswa dalam pembelajaran IPS yaitu dengan memotivasi siswa dengan sesuatu yang disenangi. Salah satu upaya yang dapat dilakukan pada permasalah diatas adalah menerapkan pembelajaran kooperatif tipe Word Square.

Menurut Slavin (2010), pembelajaran kooperatif menggalakkan siswa berinteraksi secara aktif dan positif dalam kelompok. Dengan demikian, pendidikan hendaknya mampu mengondisikan dan memberikan dorongan untuk dapat mengoptimalkan dan membangkitkan potensi siswa serta menumbuhkan aktivitas serta daya cipta (kreativitas) sehingga akan menjamin terjadinya dinamika di dalam proses pembelajaran. Dalam model pembelajaran kooperatif ini, guru lebih berperan sebagai fasilitator yang berfungsi sebagai jembatan penghubung ke arah pemahaman yang lebih tinggi, dengan catatan siswa sendiri yang belajar.

Hornby (dalam Rahmida, 2017) mendefinisikan Word Square sebagai sejumlah kata yang disusun sehingga kata-kata tersebut dapat dibaca ke depan dan ke belakang. Model pembelajaran Word Square merupakan model pembelajaran yang memadukan kemampuan menjawab pertanyaan dengan kejelian dalam mencocokan jawaban pada kotak-kotak jawaban. Mirip seperti mengisi Teka-Teki Silang tetapi bedanya jawabannya sudah ada namun disamarkan dengan menambahkan kotak tambahan dengan sembarang huruf/angka penyamar atau pengecoh. Model pembelajaran ini sesuai untuk semua mata pelajaran, tinggal bagaimana guru dapat memprogram sejumlah pertanyaan terpilih yang dapat merangsang siswa untuk berpikir efektif. Tujuan huruf/angka pengecoh bukan untuk mempersulit siswa namun untuk melatih sikap teliti dan kritis. Berdasarkan masalah dan alternatif tindakan di atas, maka peneliti tertarik untuk melaksanakan penelitian tindakan kelas dengan judul "Meningkatkan Aktivitas dan Hasil Belajar IPS pada Materi Perjuangan Melawan Penjajah Melalui Model Pembelajaran Word Square".

\section{METODE PENELITIAN Pendekatan dan Jenis Penelitian}

Pendekatan penelitian ini menggunakan pendekatan deskriptif kualitatif. Menurut Arikunto, dkk (2009), pendekatan deskriptif kualitatif menggambarkan secara objektif dan aktual tahapan proses pembelajaran. Penelitian kualitatif adalah prosedur penelitian yang menghasilkan data deskriptif berupa katakata yang dapat diamati. Jenis penelitian yang digunakan adalah penelitian tindakan kelas atau classroom action research. 
Vol. 5, No. 1, Hal (15-22)

Penelitian tindakan kelas merupakan suatu pencermatan terhadap kegiatan belajar berupa sebuah tindakan yang sengaja dimunculkan dan terjadi dalam sebuah kelas secara bersama.

Penelitian ini dilaksanakan di Madrasah Ibtidaiyah Negeri 6 Tapin terletak di Jalan Ahmad Yani KM 5 RT 2 Desa Purut Kecamatan Bungur Kabupaten Tapin. Subjek penelitian adalah siswa kelas V Madrasah Ibtidaiyah Negeri 6 Tapin tahun pelajaran 2018/2019. Jumlah siswa yang diteliti adalah 24 orang yang terdiri dari 11 orang laki-laki dan 13 orang perempuan. Pelaksanaan Penelitian Tindakan Kelas Siklus I pertemuan 1 dilaksanakan pada hari Selasa, 5 Maret 2019 dan pertemuan kedua pada hari Selasa, 12 Maret 2019. Kemudian dilanjutkan Siklus II yang pertemuan 1 dilaksanakan pada hari Selasa, 19 Maret 2019 dan pertemuan kedua pada hari Selasa, 26 Maret 2019

Permasalahan dalam penelitian ini beberapa faktor yang ingin diperbaiki:

\section{Faktor guru}

Mengamati aktivitas guru dalam proses pembelajaran dengan menggunakan model Word Squre. Aspek-aspek kegiatan atau aktivitas guru yang diamati dalam penelitian ini adalah sebagai berikut:

a. Menyampaikan materi

b. Membagi siswa dalam bentuk kelompok

c. Membagikan Lembar Kegiatan kepada siswa

d. Meminta siswa menjawab soal

e. Memberikan poin setiap jawaban dalam kotak

2. Faktor siswa

Mengamati aktivitas siswa dalam kegiatan belajar perjuangan melawan penjajah dengan menggunakan model pembelajaran Word Squre. Aspek-aspek kegiatan atau aktivitas siswa yang diamati dalam penelitian ini adalah sebagai berikut:
a. Kesungguhan dalam menerima pelajaran
b. Keaktifan
b. Kerjasama
c. Kemampuan berpendapat
d. Ketelitian
3. Faktor hasil belajar
Faktor hasil belajar adalah faktor perubahan peningkatan kemampuan siswa yang dilihat dari aspek kognitif, afektif dan psikomotor yang diukur melalui tes tertulis pada akhir kegiatan pembelajaran.

\section{Skenario Tindakan}

Penelitian tindakan kelas ini dilaksanakan dalam 2 siklus yang terdiri dari siklus I (2 kali pertemuan) dan siklus II (2 kali pertemuan).

\section{Tahap Perencanaan}

Kegiatan yang dilaksanakan dalam tahap perencanaan ini meliputi:

a. Membuat rencana pelaksanaan pembelajaran pada materi "Perjuangan Melawan Penjajah Belanda dan Perjuangan Melawan Penjajahan Jepang".

b. Membuat lembar observasi aktivitas belajar siswa dalam materi "Perjuangan Melawan Penjajah Belanda dan Perjuangan Melawan Penjajahan Jepang".

c. Membuat lembar observasi aktivitas guru untuk menganalisis PBM.

d. Menyusun alat evaluasi untuk mengukur hasil belajar siswa pada setiap akhir pembelajaran dan akhir siklus.

e. Menyiapkan penghargaan berupa piagam.

f. Menyiapkan lembar obervasi untuk mengamati kegiatan proses pembelajaran di kelas, yaitu:

g. Lembar observasi aktivitas siswa.

h. Lembar observasi aktivitas guru.

i. Menetapkan observer dengan kriteria.

1) Teman sejawat,

2) Pengalaman kerja (mengajar) minimal 10 tahun.

\section{Tahap Pelaksanaan Tindakan}

Kegiatan yang dilakukan pada tahap ini adalah melaksanakan skenario tindakan yang telah direncanakan sebanyak 2 siklus, 
Vol. 5, No. 1, Hal (15-22)

masing-masing siklus terdiri 2 kali pertemuan. Pelaksanaan siklus I dengan dua kali pertemuan meliputi kegiatan awal, kegiatan inti dan kegiatan akhir.

\section{Observasi}

Pada tahap ini dilakukan proses observasi terhadap pelaksanaan perencanaan penelitian tindakan kelas dengan mengumpulkan data terhadap aktivitas guru dan siswa dengan menggunakan lembar observasi terhadap proses pembelajaran. Sedangkan penguasaan materi pembelajaran diperoleh dari tes hasil belajar dan tes selama proses pembelajaran. Seluruh data hasil penelitian dicatat untuk dijadikan pertimbangan dalam refleksi tahap kedua.

\section{Refleksi}

Pada tahap ini dilakukan evaluasi terhadap proses pembelajaran pada Siklus I dan menjadi pertimbangan untuk memasuki Siklus II. Hasil yang diperoleh pada tahap observasi dikumpulkan dan dianalisis dalam tahap ini sebagai acuan untuk mengevaluasi diri sendiri dam hasil

\begin{tabular}{|c|c|}
\hline \multicolumn{1}{|c|}{ Pesentase } & Kategori \\
\hline $16-36 \%$ & Kurang Aktif \\
\hline $37-57 \%$ & Cukup Aktif \\
\hline $58-78 \%$ & Aktif \\
\hline $79-100 \%$ & Sangat Aktif \\
\hline
\end{tabular}

data-data tersebut dapat dilihat apakah kegiatan yang dilaksanakan tersebut sudah dapat meningkatkan hasil belajar siswa pada materi "Perjuangan Melawan Penjajahan". Pertimbangan yang digunakan jika pada siklus I ketuntasan klasikal belum mencapai indikator yang ditetapkan yaitu $70 \%$ siswa memperoleh nilai 75 .

\section{Cara Pengambilan Data}

Cara pegambilan data dilakukan dengan teknik observasi dan tes.

1. Teknik observasi yaitu dengan melakukan pengamatan terhadap siswa dan guru dalam kegiatan pembelajaran sehingga diperoleh data tentang aktivitas siswa dan guru dalam pembelajaran tersebut.
2. Teknik tes yaitu melakukan tes tertulis terhadap siswa sehingga diperoleh data tentang hasil belajar siswa.

\section{Teknik Analisis Data}

1. Aktivitas Guru

Aktivitas guru diukur berdasarkan perolehan skor dengan teknik observasi. Rumus yang digunakan adalah sebagai berikut:

Persentase $=\frac{\text { jumlah } \text { skor }}{\text { jumlah skor maksimal }} \times 100$

Tabel 1. Persentase kategori aktivitas guru

\begin{tabular}{|l|c|}
\hline \multicolumn{1}{|c|}{ Persentase } & Kategori \\
\hline $16-36 \%$ & Kurang Baik \\
\hline $37-57 \%$ & Cukup Baik \\
\hline $58-78 \%$ & Baik \\
\hline $79-100 \%$ & Sangat Baik \\
\hline
\end{tabular}

2. Aktivitas Siswa

Aktivitas siswa diukur berdasarkan perolehan skor dengan teknik observasi. Rumus yang digunakan adalah sebagai berikut:

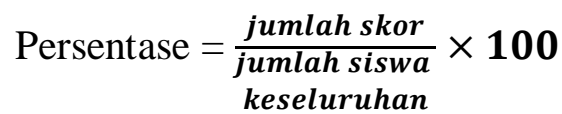

Tabel 2. Persentase kategori aktivitas siswa

\begin{tabular}{|l|c|}
\hline Persentase & Kategori \\
\hline $16-36 \%$ & Kurang Baik \\
\hline $37-57 \%$ & Cukup Baik \\
\hline $58-78 \%$ & Baik \\
\hline $79-100 \%$ & Sangat Baik \\
\hline
\end{tabular}

\section{Hasil Belajar}

Ketuntasan belajar siswa secara individual dapat dilihat nilai yang diperoleh yaitu mencapai $\geq 65$ dan secara klasikal dapat menggunakan rumus persentase sebagai berikut:

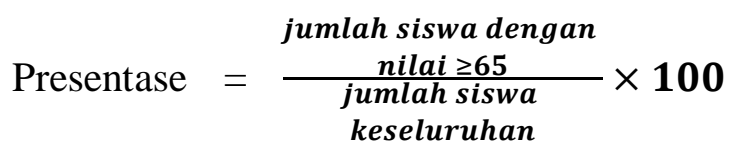

\section{Indikator Keberhasilan}

Indikator keberhasilan dari PTK ini dinyatakan berhasil apabila: 
1. Aktivitas siswa dalam pembelajaran bisa dikatakan meningkat dengan kategori sangat aktif atau persentase aktivitas siswa mencapai $79 \%$.

2. Hasil belajar siswa setelah proses pembelajaran berlangsung mengalami peningkatan dan dapat mencapai ketuntasan belajar secara individual dengan nilai $\geq 65$ sesuai yang ditetapkan dalam KKM mata pelajaran IPS kelas V, serta dapat mencapai ketuntasan belajar secara klasikal sebesar $75 \%$ mendapat nilai $\geq 70$.

\section{PEMBAHASAN \\ Siklus I \\ Hasil Observasi Pertemuan 1 \\ 1. Aktivitas Guru}

HASIL PENELITIAN DAN

Aktivitas guru dalam

mengimplementasikan model pembelajaran kooperatif tipe Word Square materi "Perjuanganan Melawan Penjajah" pada siswa kelas V Madrasah Ibtidaiyah Negeri 6 Tapin berhasil dengan kategori sangat baik. Aktivitas guru pada siklus I yaitu $73,00 \%$ dengan kriteria baik dan meningkat pada pertemuan yang kedua $85,4 \%$. Pada siklus II meningkat lagi dari 93,8\% menjadi 97,9\% dengan kriteria sangat baik. Hal ini sesuai dengan indikator keberhasilan yang ditetapkan yaitu aktivitas guru dengan kualitas pembelajarannya dikatakan meningkat apabila terlaksananya langkah-langkah pembelajaran sesuai model Word Square dengan kategori sangat baik atau persentase aktivitas guru mencapai $79 \%$. Data peningkatan aktivitas guru dijabarkan pada Tabel 1.

Tabel 1. Persentase Aktivitas Guru

\begin{tabular}{|c|l|c|c|c|c|}
\hline \multirow{2}{*}{ No } & Aktivitas Guru & \multicolumn{2}{|c|}{ Siklus I } & \multicolumn{2}{c|}{ Siklus II } \\
\cline { 3 - 6 } & $\begin{array}{c}\text { Pertemuan } \\
\text { ke-1 }\end{array}$ & $\begin{array}{c}\text { Pertemuan } \\
\text { ke-2 }\end{array}$ & $\begin{array}{c}\text { Pertemuan } \\
\text { ke-1 }\end{array}$ & $\begin{array}{c}\text { Pertemuan } \\
\text { ke-2 }\end{array}$ \\
\hline 1. & Kegiatan Awal & $66,70 \%$ & $75,00 \%$ & $100 \%$ & $100 \%$ \\
\hline 2. & Kegiatan Inti & $75,00 \%$ & $91,7 \%$ & $91,7 \%$ & $95,8 \%$ \\
\hline 3. & Kegiatan Akhir & $75,00 \%$ & $83,3 \%$ & $91,7 \%$ & $100 \%$ \\
\hline $\begin{array}{c}\text { Persentase } \\
\text { (skor maksimal 48) }\end{array}$ & $73,00 \%$ & $85,4 \%$ & $93,8 \%$ & $97,9 \%$ \\
\hline \multicolumn{2}{|}{ Kriteria } & Baik & Sangat Baik & Sangat Baik & Sangat Baik \\
\hline
\end{tabular}

\section{Aktivitas Siswa}

Aktivitas siswa dalam kegiatan pembelajaran materi perjuangan melawan penjajah dengan menggunakan model pembelajaran kooperatif tipe Word Square meningkat. Pada siklus I pertemuan 1 memperoleh nilai $62,8 \%$ meningkat pada pertemuan ke 2 yaitu 71,87\%. Aktivitas siswa dalam siklus II pertemuan 1 sebesar $81,45 \%$ dan meningkat lagi pada pertemuan 2 yaitu sebesar $95 \%$ dengan kategori sangat aktif.
Peningkatan aktivitas siswa diperoleh dari 5 aspek yang diamati yaitu kesungguhan dalam menerima pelajaran, keaktifan, kerjasama, kemampuan berpendapat, dan ketelitian. Hal ini sesuai dengan indikator keberhasilan yang ditetapkan yaitu aktivitas siswa dalam pembelajaran bisa dikatakan meningkat dengan kategori sangat aktif atau persentase aktivitas siswa mencapai $79 \%$. Data aktivitas siswa dijabarkan pada Tabel 2. 
Tabel 2. Persentase Aktivitas Siswa

\begin{tabular}{|c|c|c|c|c|c|}
\hline \multirow{3}{*}{ No } & \multirow{3}{*}{ Kelompok } & \multicolumn{4}{|c|}{ Aktivitas Siswa } \\
\hline & & \multicolumn{2}{|c|}{ Siklus I } & \multicolumn{2}{|c|}{ Siklus II } \\
\hline & & Pertemuan ke-1 & Pertemuan ke-2 & Pertemuan ke-1 & Pertemuan ke-2 \\
\hline 1. & $\mathrm{I}$ & $62,50 \%$ & $72,50 \%$ & $75,00 \%$ & $87,50 \%$ \\
\hline 2. & II & $67,50 \%$ & $80,00 \%$ & $92,50 \%$ & $100 \%$ \\
\hline 3. & III & $65,00 \%$ & $80,00 \%$ & $92,50 \%$ & $97,50 \%$ \\
\hline 4. & IV & $65,00 \%$ & $77,50 \%$ & $85,00 \%$ & $95,00 \%$ \\
\hline 5. & $\mathrm{~V}$ & $53,50 \%$ & $55,00 \%$ & $62,50 \%$ & $95,00 \%$ \\
\hline 6. & VI & $55,00 \%$ & $65,00 \%$ & $77,50 \%$ & $95,00 \%$ \\
\hline \multicolumn{2}{|c|}{ Rata-rata } & $62.08 \%$ & $71,87 \%$ & $81,45 \%$ & $97,90 \%$ \\
\hline \multicolumn{2}{|r|}{ Kriteria } & Aktif & Aktif & Sangat Aktif & Sangat Aktif \\
\hline
\end{tabular}

\section{Hasil belajar siswa}

Pembelajaran kooperatif tipe Word Square dapat meningkatkan hasil belajar siswa kelas V Madrasah Ibtidaiyah Negeri 6 Tapin pada pembelajaran IPS materi "Perjuangan Melawan Penjajah". Hal ini sesuai dengan indikator keberhasilan yang ditetapkan yaitu hasil belajar mengalami peningkatan dan dapat mencapai ketuntasan belajar secara individual. Siklus I pertemuan 1 memperoleh ketuntasan individual sebesar 41,66\%, pada pertemuan ke 2 sebesar $75 \%$. Pada siklus II pertemuan 1 91,7\% dan padapertemuan ke 2 sebesar $95,83 \%$ dengan nilai $\geq 65$ sesuai yang ditetapkan dalam KKM mata pelajaran IPS kelas $\mathrm{V}$ serta dapat mencapai ketuntasan belajar secara klasikal sebesar $75 \%$ mendapatkan nilai $\geq 70$. Data hasil belajar siswa selanjutnya dijabarkan pada Tabel 3 dan Tabel 4.

Tabel 3. Hasil Belajar

\begin{tabular}{|c|c|c|c|c|c|}
\hline \multirow{2}{*}{ No } & \multirow{2}{*}{ Kelompok } & \multicolumn{4}{|c|}{ Nilai Kerja Kelompok } \\
\cline { 3 - 6 } & & \multicolumn{2}{|c|}{ Siklus I } & \multicolumn{2}{c|}{ Siklus II } \\
\cline { 3 - 6 } & & $\begin{array}{c}\text { Pertemuan } \\
\text { ke-1 }\end{array}$ & $\begin{array}{c}\text { Pertemuan } \\
\text { ke-2 }\end{array}$ & $\begin{array}{c}\text { Pertemuan } \\
\text { ke-1 }\end{array}$ & $\begin{array}{c}\text { Pertemuan } \\
\text { ke-2 }\end{array}$ \\
\hline 1. & I & 65 & 80 & 90 & 100 \\
\hline 2. & II & 85 & 90 & 90 & 100 \\
\hline 3. & III & 80 & 85 & 90 & 100 \\
\hline 4. & IV & 75 & 80 & 90 & 100 \\
\hline 5. & V & 60 & 75 & 80 & 90 \\
\hline 6. & VI & 60 & 70 & 80 & 90 \\
\hline
\end{tabular}

Tabel 4. Ketuntasan Individual

\begin{tabular}{|c|c|c|c|c|c|}
\hline \multirow{2}{*}{ No } & \multirow{2}{*}{ Kelompok } & \multicolumn{3}{|c|}{ Ketuntasan Individual } \\
\cline { 3 - 6 } & & \multicolumn{2}{|c|}{ Siklus I } & \multicolumn{2}{c|}{ Siklus II } \\
\cline { 3 - 6 } & & $\begin{array}{c}\text { Pertemuan } \\
\text { ke-1 }\end{array}$ & $\begin{array}{c}\text { Pertemuan } \\
\text { ke-2 }\end{array}$ & $\begin{array}{c}\text { Pertemuan } \\
\text { ke- } 1\end{array}$ & $\begin{array}{c}\text { Pertemuan } \\
\text { ke-2 }\end{array}$ \\
\hline 1. & Tuntas & $41,66 \%$ & $75,00 \%$ & $91,70 \%$ & $95,83 \%$ \\
\hline 2. & Tidak Tuntas & $58,34 \%$ & $25,00 \%$ & $8,30 \%$ & $4,17 \%$ \\
\hline
\end{tabular}




\section{PENUTUP}

Berdasarkan hasil analisis dan pembahasan, dapat disimpulkan bahwa penerapan model pembelajaran Word Square dapat meningkatkan aktivitas dan hasil belajar mata pelajaran IPS materi perjuangan melawan penjajah pada siswa kelas V MIN 6 Tapin.

Hasil penelitian menunjukkan bahwa aktivitas siswa siklus I pertemuan 1 adalah $62,80 \%$, pertemuan 2 adalah $71,87 \%$. Sedangkan pada siklus II pertemuan 1 adalah sebesar $81,45 \%$ dan pada pertemuan 2 sebesar $97,90 \%$. Hasil belajar siswa mengalami peningkatan dan dapat mencapai ketuntasan belajar secara individual pada siklus I pertemuan 1 sebesar 41,66\% kemudian meningkat pada pertemuan 2 sebesar $75,00 \%$. Pada siklus II pertemuan 1 sebesar $91,70 \%$ dan meningkat pada pertemuan 2 sebesar $95,83 \%$.

\section{DAFTAR PUSTAKA}

Arikunto, S, dkk. 2009. Penelitian Tindakan Kelas. Jakara: PT Bumi Aksara.

Badan Standar Nasional Pendidikan (BSNP). 2006. Paduan Pelaksanaan Sistem Pendidikan (Undang-Undang Repubik Indonesia Nomor 20 Tahun 2003). Jakarta: Depdiknas.

Nurdianti, A. 2016. Upaya Meningkatkan Aktivitas dan Hasil Belajar Ilmu Pengetahuan Sosial Melalui Penerapan Model Kooperatif Tipe Students Teams-Achievment Divisions, (Online), (http://repository.unpas.ac.id/4971/), diakses 1 April 2019.

Rahmida, M. 2017. Meningkatkan Motivasi dan Hasil Belajar Siswa Kelas VII A Melalui Metode Observasi yang Divariasikan dengan LKS Word Square pada Materi Klasifikasi Hewan di SMP Negeri 1 Banua Lawas. Jurnal Langsat, 4 (1), 51-59.
Slavin, R.E. 2010. Cooperative Learning: Teori, Riset dan Praktik. Bandung : Nusa Media.

Targana, T.A. 2009. Pembelajaran IPS di Sekolah Dasar Berbasis Pembelajaran Tematik. Jurnal Pendidikan Dasar EduHumaniora UPI Kampus Cibiru, 1(2). Dari http://ejournal.upi.edu/ index.php/eduhumaniora/article/view/ 2736/1784. 
Jurnal PTK \& Pendidikan

Vol. 5, No. 1, Hal (15-22) 